УДК 1 (091) 125:171

https://doi.org/10.33989/2075-1443.2020.43.212693

orcid.org/ 0000-0003-3097-7974

\title{
Володимир Попов
}

ПОПОВ Володимир Юрійович - доктор філософських наук, професор кафедри філософії Донецького національного університету імені Василя Стуса (м. Вінниия, Украӥна). Сфера наукових інтересівісторія світової філософії, сучасна метафізика.

\section{DASEIN I WELTANSHCAUUNG: ГАЙДЕГЕРІВСЫКІ ЕКСПЛІКАЦЇ̈ СВІТОГЛЯДУ}

У дослідженні розкривається особливість тлумачення Мартіном Гайдегером поняття «світогляд» та його співвідношення з філософією (метафізикою). Зазначається, щчо Гайдетер досить скептично ставився до концепту «Weltanshcaunng», розглядаючи його в контексті власної «метафізики Dasein». Увага приділясться еволюиї поглядів німецьького мислителя, впливу на його думку нацистської ідеології. Розкриваються особливості екзистенціальної аналітики Гайдегера.

Ключові слова: Dasein, Weltanshcaunng, світогляд, феноменологія, екзистениіальна аналітика, нацистська ідеологія, Weltbild, картина світу, деконструкиія.

Постановка проблеми. Мартін Гайдегер вважається ключовою постаттю європейської «континентальної» філософії XX сторіччя. Навіть за життя його вважали класиком світової філософії. Ще в 1931 році тоді ще палкий його прихильник Емануель Левінас називав його «найвеличнішим філософом у світі». А сучасний російський філософ та ідеолог євразійства О. Дугін розмірковує: чи є він «просто» великим чи $є$ найвеличнішим. 3 новою силою інтерес до творчості Гайдегера спалахнув у європейській інтелектуальній спільноті починаючи з 2013 року, коли почалася публікація його «Чорних зошитів»: його таємні щоденники, які німецький філософ вів з 1933 по 1945 рік. Ця публікація розпалила дискусію про ступінь причетності мислителя до нацизму, що здавалося вже

(C) В. Ю. Попов, 2020 
вщухла в філософському середовищі. Тобто популярності мислителя не заважає (а може й декого приваблює) навіть його свідома співпраця з нацизмом під час перебування ректором Фрайбурзького університету. Чи відповідало це глибинному духу його філософії, чи було просто соціальним конформізмом або помилкою - про це й досі йде полеміка у філософській і публіцистичній літературі. Його спосіб філософування й досі породжує у критиків та дослідників відчуття майже містичної таємниці, його тексти ніби стосуються зрозумілих речей, що беруть свої витоки у людському повсякденні, але написані у напівхудожньому, напівафористичному специфічному стилі та вперто не хочуть ставати зрозумілими до очевидності, розкриватися перед «непосвяченими».

Аналіз останніх досліджень і публікацій. Дослідженню творчості Гайдегера ще за його життя та й потім було присвячено чимало книг, статей та захищених дисертацій. Своїм мовчанням не обходять цю філософську постать всі дослідники історії філософії XX сторіччя. У сучасному гайдегерізнавстві здається вже розкриті більшість концептів мислителя, їх походження та філософські експлікації.. Тим не менш один з концептів майже залишився поза увагою як західних, так і вітчизняних дослідників. Це поняття «Weltanschauung», яке перекладається українською як «світогляд». Але саме воно грає непересічну роль у гайдегерівській «філософії понять». Про це свідчить монографія, яка опублікована в Штутгарті з досить символічною назвою «Weltanschauung - eine Herausforderung für Martin Heideggers Philosophiebegriff (Світогляд як виклик філософії понять Мартіна Гайдегера)» в 2009 році (Müller, 2009). Автор цієї книги, німецький дослідник Арнульф Мюллер на підставі достатньо ретельного дослідження історії поняття «Weltanschauung» та гайдегерівських текстів, присвячених цьому концепту, прийшов до висновку, що філософія Гайдегера в остаточному підсумку є боротьбою зі світоглядом, який $\epsilon$ нічим іншим як «Unwesen (безчинством)» метафізики (Müller, 2009, p. 423). 3 повагою ставлячись до напрацювань Мюллера все ж треба зазначити певні змістовні лакуни, які залишилися поза увагою дослідника та деякі перебільшення, викликані науковим стилем автора. Цікавим доповненням до цієї монографії вдається монографія Ігоря Михайлова (Михайлов, 1999) та особливо остання стаття російського дослідника Іллі Дьоміна «Співвідношення науки та світогляду у світлі фундаментальної онтології М. Гайдегера» (Демин, 2015), хоча автор більше зосереджує увагу саме на взаєминах науки та світогляду. Не бракує праць, присвячених філософії Гайдегера й в українському історико-філософському дискурсі. Найбільшу значимість для нашого дослідження мали статті А. Дахнія, С. Шевченка, І. Канівця та С. Мигаля 
(хоча остання скоріше в контраверсійному сенсі), але в жодній 3 них увага не зосереджена на опрацьовуванні Гайдегером саме концепту «Weltanschauung».

Певним чином, спираючись на вищевказані розвідки, ми в своїй статті поставили за мету дослідити зв' язок концептів «Weltanschauung» та «Dasein», який майже не розкритий в вищеназваних роботах, динаміку деконструкції Гайдегером концепту «світогляд» та, зокрема, його відношення до його профанного розуміння та популяризації в офіційній нацистський ідеології та пропаганді. Можливо виконання останнього завдання допоможе по-новому поглянути на проблему стосунків Гайдеггера та нацизму.

Виклад основного матеріалу. Поняття «Weltaschauung (світогляд)» на початку XX сторіччя займає чільне місце в німецькій філософіï: роботи В. Віндельбанда, Г. Ріккерта, а особливо В. Дільтая початку $\mathrm{XX}$ сторіччя заклали вже певну концептуальну схему співвідношення світогляду і філософії. Неокантіанство і «філософія життя» виробили дві, до певної міри, протилежні позиції. Якщо перша наголошувала на тому, що світогляд як цілісна картину світу виникає на основі філософського осмислення світу, то друга, визначаючи його як умонастрій або систему ціннісних переконань, вбачала в ньому психологічне підгрунтя філософії. Едмунд Гусерль зайняв третю, зовнішньо непримиренну до психологізованої версії концепту світогляду, позицію. Наголошуючи на тому, що світогляд має особистісний та тимчасовий характер, він стверджував, що «Світогляди можуть сперечатися; тільки наука може вирішувати, і іï рішення несе на собі печатку вічності» (Гуссерль, 2005 , c. 236).

Мартин Гайдегер починав свою філософську кар'єру, позбавившись первинного католицького впливу, як прибічник феноменології, вірний учень та соратник Гусерля в Фрайбурзькому університеті. В своїх перших філософських напрацюваннях Гайдегер намагається розмежовувати поняття світогляд і філософію всупереч пануючій у кінці XIX - початку XX сторіччя неокантіанській філософській традиції та надати світогляду феноменологічного тлумачення.

Вже в роботі «Die Idee der Philosophie und das Weltanshcauungsproblem (Ідея філософії та проблема світогляду)» (Heidegger, 1999), написаній в 1919 році Гайдегер як новонавернений в «феноменологічну віру», вважає, що філософія повинна стати «первинною» наукою, приставляючи ії так званій «світоглядній філософії». Але вірний послідовник Гусерля не лише чисто формально відтворює його основні позиції з цього питання, але й намагається надати дилемі «філософія-світогляд» логічного вигляду та заверше- 
ності. Він стверджує, що світогляд або «1) є іманентним завданням філософії, і тоді остання виявляється в кінці кінців ідентичною світогляду, або 2) світогляд межує з філософією, і остання в цьому випадку 3 світоглядом не ідентична». Дилема «зрозумілим чином вирішується на користь другого» (Heidegger, 1999, p. 18). Проте, як би не вирішувалася ця дилема, ясно одне: філософія і світогляд або ідентичні, або ні, - але якийсь взаємозв'язок між ними $\epsilon$.

Але Гайдегер пропонує й досить оригінальний хід думки. Ніби тільки для «повноти і точності методу» він бажає «на всяк випадок» розглянути й іншу абстрактну можливість: а що, якщо ніякого взаємозв'язку між філософією і світоглядом немає взагалі?

На перший погляд, ця можливість є порожньою і чисто формальною, проте в її світлі вся проблематика лекцій несподівано постає під іншим кутом зору: «Якщо раптом буде доведено, що формування світогляду жодним чином, в тому числі й як межове завдання не належить філософії - так, що воно є феноменом, стороннім філософії, - тоді сутність світогляду стає проблемою» (Heidegger 1999, p. 26). Молодий філософ не дає остаточної відповіді на це питання, але вже намічені певні шляхи до деструкції поняття «Weltanscauung».

У 1920 році відбувається зустріч Гайдегера з Карлом Ясперсом, новоопублікована книга якого «Психологія світоглядів» справляє на нього незабутнє враження (на протязі 1920-1921 років він пише велику рецензію на неї), й погляди молодого фрайсбурського професора на сутність світогляду дещо змінюються. Наскільки він приймає ясперівську психолого-індивідуалістичну версію концепту «Weltanscauung», чи відмовляється він від гусерліанського його тлумачення? Взаємовплив Гайдегера та Ясперса, яких в 1922-1933 поєднувала «бойова співдружність», був достатньо сильним, таким що сучасний російський дослідник Ігор Михайлов вважає Ясперса «співавтором» гайдегерівського Opus magnum - знаменитого трактату «Буття та час» (Михайлов 1999, с. 166), який називають «Біблією новітньої європейської філософії».

Втім, в самому «Zein und Seit», який перенасичений новою власне гайдегерівською термінологією (зокрема найбільш поширеним є запозичений у Ясперса термін «Dasein», який у своєрідному тлумаченні швабського Майстра стане своєрідною «візитівкою» його філософіï), ми не зустрінемо ні «Weltanshcauung», ні «Weltanschauungsphilosophie».

Проблема сутності світогляду та його співвідношення з філософією знаходить своє відображення в лекціях, прочитаних Гайдегером у Марбургському університеті в 1927 році та виданих згодом під назвою «Die Grundprobleme der Phänomenologie (Основні проблеми феноме- 
нології)» (Хайдеггер, 2001). Сам автор вказував, що вони є своєрідним доповненням, новою розробкою третього розділу першої частини «Буття та часу».

Саме в цій праці Гайдегер проводить етимологічну деструкцію терміну «Weltanshcauung» від його винайдення Кантом до новітнього тлумачення його значення Ясперсом. Він проголошує, що «це слово не $\epsilon$ перекладом з грецької або, скажімо, латини. Немає такого виразу, як космотеорія. Навпаки, це слово власне німецького чекану, й воно було викарбовано саме в філософії» (Хайдеггер, 2001, с. 5). Але його головна мета (намічена вже в «Ідеях філософії та проблемі світогляду») полягає в тому, щоб принципово розмежувати філософію та світогляд, позбавитися від неокантіанських «чар» світоглядної філософії. Засобом позбавлення стає звернення до творів самого Канта та власне їх перетлумачення. Зокрема, Гайдегер віднаходить джерело сучасних суперечок між феноменологами й неокантіанцями в «Логіці» («Logik. Ein Haudbuch zu Vorlesungen» кантівського посібника до лекцій, виданого в 1800 році). Він наводить аналогію між кантівським поділом філософії на філософію в схоластичному значенні і філософію у значенні світового громадянства з сучасним поділом філософії на «наукову» (wissenschaftliche Philosophie) та «світоглядну» (Weltanschauungsphilosophie) (Хайдеггер, 2001, с. 9).

Але, з характерною гайдегерівською двозначністю й туманністю, повна аналогія тут відкидається. «Чи збігається це кантівський поділ філософії на філософію в схоластичному значенні і філософію у значенні світового громадянства 3 відмінністю наукової філософії і світоглядної філософії?» - риторично запитує Гайдегер. Й відповідає: «Так і ні. Так, оскільки Кант взагалі проводить розмежування усередині поняття філософії й на підставі цієї диференціації розташовує в центрі кінцеві й граничні питання людського Dasein. Hi, оскільки у філософії згідно світовому поняттю немає завдання формувати світогляд у зазначеному вище сенсі. Те, що в кінцевому підсумку уявлялося Канту, хоча він і не зумів висловити цього явно, у тому числі і як завдання філософії в значенні світового громадянства, є не що інше, як апріорна і онтологічне окреслення тієї визначеності, яка належать суті людського Dasein і яка визначає поняття світогляду взагалі» (Хайдеггер, 2001, с. 10).

Розуміння філософії як теоретичної форми світогляду, впроваджене неокантіанством, стало настільки само собою зрозумілим, що воно «звично і повсюдно визначає поняття філософії i, тим самим, вказує розхожій свідомості, чого можна чекати від філософії й що повинно від неї чекати» (Хайдеггер, 2001, с. 7). Але для Гайдегера філософія 
$\epsilon$ насамперед онтологією, наукою про буття. Поняття ж «світоглядної філософії» оголошується ним безглуздим на тій підставі, що будьякий світогляд має справу з сущим і покладанням сущого (Setzung von Seiendem), воно задає певну установку у відношенні до сущого. «Якщо хоча б приблизно розкрити поняття філософії та іiї історії, пише Гайдегер, - то поняття світоглядної філософії виявляється чимось на зразок круглого квадрату» (Хайдеггер, 2001, с. 10). Світогляд дає людині систему уявлень про суще в цілому (про «світ») і відповідає на питання про місце людини у світі. Філософія ж нічого не говорить про суще в аспекті його змісту, але лише в аспекті його буття. Власною темою філософії як фундаментальної онтології виступає не суще, а буття сущого. Чи означає це, що філософія взагалі нічого не може сказати про світогляд? Нi, не означає. Оскільки світогляд є щось таке, що «завжди історично існує з фактичного Dasein, разом 3 ним i для нього», а сама філософія (онтологія) можлива лише як екзистенціальна аналітика Dasein, світогляд неминуче виявляється в полі зору філософії як сутнісної характеристики людського існування як такого, в якості одного 3 «екзистенциалів» Dasein.

Філософія як екзистенціальна аналітика Dasein, повинна відповісти на питання, що таке світогляд взагалі і чому він з необхідністю належить людському буттю, але філософія безпосередньо не займається вирішенням світоглядних питань, нічого не говорить ні за, ні проти того чи іншого конкретного світогляду або того чи іншого типу світогляду. Філософія як наука про буття не займається формуванням світогляду, не бере участі у формуванні світогляду і не може виконувати ніяких світоглядних «функцій». «Філософія може i, ймовірно, має в числі іншого показати, що сутності Dasein належить щось таке як світогляд. Філософія може і повинна окреслити те, що становить структуру світогляду взагалі. Але вона ніколи не може утворити і заснувати той чи інший певний світогляд» (Хайдеггер, 2001, с. 11). Отже, філософія (в гайдегерівському іiі розумінні) може задаватися питаннями про світогляд, але вона безпосередньо не має справи з самими світоглядними питаннями, оскільки останні завжди запитують про суще (про суще в цілому або про те чи іншому типі сущого - природу, людину, Бога, суспільстві, історії тощо). Світогляд не є єдиною або навіть пріоритетною темою філософії, він цікавить філософію лише в тій мірі, в якій проблема сутності світу в цілому становить невід'ємною характеристикою людського буття-в-світі.

B контексті екзистенціальної аналітики Dasein значення має лише сам факт того, що людському буттю належить щось таке, як «світогляд». Конкретні джерела світогляду (релігія, наука, повсякденний до- 
свід і т. д.) і його змістовна специфіка не мають для філософії жодного значення і не є філософськими проблемами: «Визначається світогляд марновірствами й забобонами, або ж спирається на суто наукове пізнання і досвід, або, як це зазвичай і буває, сплітається з забобонів і знань, пересудів і спроб усвідомлення, - не має значення і нічого не змінює в його суті» (Хайдеггер, 2001, с. 7).

Таким чином, у Марбургських лекціях 1927 року відбувається радикальне розмежування Гайдегера $з$ розхожим «світоглядним» розумінням філософії, він виносить поняття «Weltanschauung» за межі фундаментальної онтології, втім не відмовляється від нього, вважаючи його засобом саморозуміння і самотлумачення людського Dasein щодо світу.

На кінець 1920-х років припадає своєрідний філософський «кайрос» М. Гайдегера, апогеєм якого став знаменитий Давоський диспут 3 Ернстом Кассірером навесні 1929 року. На ньому також (хоча й досить побічно) підіймалася проблема сутності світогляду та його співвіднесення з філософією «Хіба не справа філософії виробляти світогляди?» - іронічно звертається до аудиторії Гайдеггер. Але тут же зауважує: «Філософ не пропонує світогляду прямо і за допомогою доктрини. Скоріше відбувається так, що може виявитися можливим, в процесі філософування, радикально усвідомити трансцендентність самого існування, тобто внутрішню можливість цієї конечної істоти подивитися в обличчя буттю як такому» (Heidegger, 2010, p. 226).

Давос-29 сучасними філософами розглядається як досить символічна подія: інтелектуальна перемога Гайдегера свідчила про відхід європейської філософії від просвітницьких засад гуманізму й раціональності та появу нової філософії, що намагається побудувати нові засади світобачення. В Німеччині все більшої популярності набуває Völkischephilosophie (народна філософія) на яку спираються ідеологи так званої «консервативної революції» (брати Юнгери, К. Шмітт та ін.). Мартін Гайдегер також приєднується до цього ідейного руху.

I справа не лише у «гріхопадінні» фрайбурського філософа (який, як відомо, в 1933 році обирається за нацистською підтримкою ректором університету та стає членом НСДАП), а й в цілком свідомому прагненні не тільки служити новому режимові, а й стати «духовним фюрером» Третього Райху. Втім, незабаром Гайдегер зазнає повної поразки в здійсненні своїх амбітних домагань. Нацистський режим не мав потреби в досить незрозумілих для більшості промовах філософа, який намагався втілити в життя свої антиметафізичні ідеї повернення до справжнього Dasein. Його погляди щодо сутності світогляду також не вписувалися в офіційну ідеологічну доктрину. Тим більш, що сам амбітний фрайбур- 
ський професор гребував «непрофесійними балачками на світоглядні теми», якими були насичені промови і праці ідеологів Третього Райху. Він в своїх лекціях піддавав критиці деякі концепти провладних філософів, зокрема «світогляд», «цінності», тотальність» тощо, вважаючи їх поняттями сучасного нігілізму. Хоча в останньому звинувачували й самого Гайдегера й самі опоненти: зокрема його якось назвали філософом, якого «не розуміє ніхто і викладає... Ніщо», а його колишній колега Ернст Крик, який претендував на роль «офіційного філософа» націоналсоціалістського руху, висловився ще виразніше: «Сенс цієї [гайдегерівської] філософії - відвертий атеїзм і метафізичний нігілізм, представлений у нас переважно єврейськими літераторами, тобто фермент, що сприяє розкладанню і розпаду німецького народу» (Сафрански, 2005, с 219). Але не полишаючи надії бачити в нацизмі втілення своїх філософських прагнень, Гайдегер в одній з своїх лекцій літнього семестру 1935 року (яка згодом було опублікована в 1953 у збірці «Вступ до метафізики») проголошував: «Те, що сьогодні кинуто на ринок у формі філософії націонал-соціалізму, не має ніякого відношення до істини і величі цього руху (тобто з осмисленням зв'язків і відповідностей між сучасною людиною і планетарно детермінованої технікою) і ловить рибку в каламутній воді “цінностей“" i “тотальностей“» (Heidegger, 2000, p. 126).

Зберігаючи політичну відданість режимові (Гайдегер до 1945 року залишався членом НСДАП), він відходить у внутрішню опозицію, намагаючись знайти порятунок німецького духу у поверненні до досократиків, Гельдерліна та Ніцше. Саме в цей період, який інколи називають «мовчазним», Гайдегер здійснює остаточну концептуалізацію поняття «світогляд», визначаючи його місце в розвитку західної духовності та межі його застосування. Цей остаточний вирок він виносить у доповіді «Обгрунтування новоєвропейської картини світу метафізикою», прочитаній у червні 1938 року у Фрайбурзі в серії лекцій, організованих Товариством мистецтвознавства, природознавства і медицини, яка згодом була відтворена у роботі «Die Zeit des Weltbildes (Час картини світу)» (опублікована в 1950 р.) (Heidegger, 2003).

В своїй доповіді Гайдегер ставить за мету осмислити сутність Нового часу, його метафізику та «концепцію істини». Він визначає п'ять «сутнісних явищ», що визначають цю епоху. Це, насамперед, інструментальна наука, «рівне їй за рангом» явище машинної техніки, естетизація мистецтва, культурна політика та десакралізація, тобто обезбоження. Всі вони базуються на «основоположній метафізичній установці», яка перетворює людину в «суб'єкта», для якого світ стає лише сукупністю «об’ єктів», тобто щось ӥй протилежне. Більш того світ людина Модерну сприймає сам світ як певну картину світу - «Weltbild». 
Гайдегер намагається віднайти метафізичні підстави цієї «картини світу» або «наукового світогляду», які виникають в філософії Декарта та математизованій фізиці. Німецькі терміни «Weltanschauung» (світогляд) i «Weltbild» (картина світу або образ світу) досить пов'язані за сенсом але, перше більш пов'язане з переконаннями, а друге з поглядами ${ }^{1}$. Новий час («сучасність») як «час картини світу» 6 , за Гайдегером, також і часом світогляду, «епохою панування світогляду». Мова йде не про панування якогось певного світогляду або типу світогляду, який приходить на зміну іншому. Мова йде про те, що світогляд як такий в Новий час стає панівним способом саморозуміння людини та розуміння світу. «Оскільки світ стає картиною, позиція людини розуміється як світогляд» - проголошує Гайдегер (Heidegger, 2003, p. 79). Він рішуче заперечує проти застосування цього поняття щодо духовності інших епох та інших культур: «не можливо помислити середньовічний і настільки ж абсурдним є католицький світогляд» (Heidegger, 2003, p. 79). Саме перетворення людської суб'єктивності в «світогляд» виробляє принципово нове відношення людини до світу. Воно не $є$ в жодному разі бездіяльним спогляданням. Гайдегер вважає, що «...вже в XIX ст. почали справедливо підкреслювати, що світоглядна позиція означає також, і навіть, в першу чергу, життєву позицію» (Heidegger, 2003, p. 81). Він стверджує, що саме з'явлення концепту «світогляд» $є$ ознакою появи нового світотлумачення та нового типу відношення до світу та життєвої позиції: «Так чи інакше, поява слова «світогляд» як імені для позиції людини посеред сущого свідчить про те, як рішуче світ став картиною, коли людина звела власне життя в якості суб'єкта до командного положення загальної точки відліку» (Heidegger, 2003, p. 82).

В своїх лекціях з філософії Ніцше, які Гайдегер викладав з 1936 року він висловився з цього приводу ще виразніше: «Світогляд $є$ тим ликом новоєвропейської метафізики, який стає неминучим, коли розпочинається ії̈ завершення до безумовності. Наслідок - своєрідне уніформування різноманітної досі західноєвропейської історії; іiі «уніформність» дає про себе знати метафізично у спарування «ідеї» і «цінності» як провідного інструмента світоглядного витлумачення світу. Через таке спарування ідеї і цінності з сутністю ідеї зникає характер

1. В сучасній німецькій мові можна казати про більш-менш чітке розмежування значень та визначення царин використання термінів «Weltbild» та «Weltanschauung». Перший означає наукове «світобачення», або «картину світу», притаманну тій чи іншій науковій парадигмі, другий - має більш широке значення: від особистих переконань (релігійної віри) до філософської доктрини або політичної ідеології. В середині XX сторіччя цього чіткого розмежування ще не було й інколи ці поняття змішувалися й накладались один на одне. 
буття і його розрізнення від сущого. ... Влада світогляду взяла сутність метафізики у своє володіння. Своєрідність усієї метафізики, що полягала у іiі ж здатності до розрізнення буття і сутності, з необхідності стає для неї байдужим і ставиться під запитання - це виступає тепер тією рисою, яка відрізняє метафізику як світогляд. Тут закладена основа того, що з початком завершення метафізики вперше може розгорнутися повне, безумовне, нічим непорушне і поза сумнівне панування над сущим» (Heidegger, 1996, p. 159).

Але повернемося до «Часу картини світу». Гайдегер завершує свою доповідь своєрідним «діагнозом» сучасності в якому вказує, що світ вступає в стадію жорстокої конфронтації між конкуруючими проектами оволодіння світом - американізмом, комунізмом та націоналсоціалізмом. «Основні установки» трьох світоглядів чітко розмежовані і рішуче захищаються їх прихильниками, проте все це відбувається на грунті технократичного світогляду Модерну. «Заради цієї боротьби... людина вводить в дію необмежену могутність загального розрахунку, планування і організації» (Heidegger, 2003, p. 114). Розрахунок характерний для американізму, планування - для комунізму, організація для націонал-соціалізму.

Але всі свої надії фрайбурський мислитель покладає на таємниче «Непередбачуване (Unberechenbare)», яке «невидимою тінню нависає над усіма речами». Він стверджує, що саме «воно перенесе майбутню людину туди, де вона буде належати буттю і все ж залишатися чужинцем серед сущого». Пророцтво про подолання епохи «картини світу» або світогляду завершується уривком віршу Гельдерліна, в якому той міркує про короткий «вік народів» (Heidegger, 2003, p. 115).

Після Другої світової війни Гайдегеру прийшлося пережити й роки інтелектуальної ізоляції та ідеологічної дискредитації й час певного виправдання (не без допомоги Г. Арендт) та всесвітнього визнання. Втім, у його творах в який він довершує побудову власної «фундаментальної онтології» місця для концепту «Weltanschauung», який мав дещо «заплямовану» нацистською ідеологією репутацію, вже не знаходиться...

Висновки. Отже, концепт «світогляд», згідно Гайдегеру, не можна розглядати як поняття більш загальне ніж «сучасна картина світу», він має минущий та історично визначений характер. Світогляд як такий $€$ породженням об'єктивованої науки Нового часу і є способом саморозуміння і самотлумачення Dasein у сучасну епоху. Він має справу 3 сущим, а не з буттям. «Релігія» та «міфологія» в контексті гайдегерівської фундаментальної онтології є не типами світогляду, але засобами самотлумачення (Selbstauslegung) Dasein і корелятивного йому 
світотлумачення (Weltauslegung). Тобто справжня філософія повинна обмежити застосування штучного терміну «світогляд», застосовуючи його лише до специфічної форми світотлумачення епохи Модерну.

\section{Сиисок використаних джерел}

Гуссерль Э. Философия как строгая наука. Избранные работы / сост. В. А. Куренной. Москва : Издательский дом «Территория будущего», 2005. C. $185-240$.

Дёмин И. В. Соотношение науки и мировоззрения в свете фундаментальной онтологии М. Хайдегера. Вестник СГАУ. 2015.1 (14). С. 225-234.

Михайлов И. А. Ранний Хайдеггер: между феноменологией и философией жизни. Москва : Прогресс-Традиция, 1999.

Сафрански Р. Хайдеггер: германский мастер и его время. Москва : «Молодая гвардия», 2005

Хайдеггер М. Основные проблемы феноменологии. / пер. с нем. А. Г. Чернякова. Санкт-Петербург : Высшая религиозно-философская школа, 2001.

Heidegger M. Davoser Disputation zwischen Ernst Cassirer und Martin Heidegger. Kant und das Problem der Metaphysik. Frankfurt am Main: Vittorio Klostermann Verlag, 2010.

Heidegger M. Die Idee der Philosophie und das Weltanschauungsproblem (Kriegsnotsemester 1919). Frankfurt am Main: Vittorio Klostermann Verlag, 1999.

Heidegger M. Die Überwindung der Metaphysik.Vorträge und Aufsätze (19361953). Frankfurt am Main: Vittorio Klostermann Verlag, 2000.

Heidegger M. Die Zeit des Weltbildes. Holzwege (1935-1946). Frankfurt am Main: Vittorio Klostermann Verlag, 2003.

Heidegger M. Nietzsche: Der Wille zur Macht als Kunst (Winter semester 1936/37). Frankfurt am Main: Vittorio Klostermann Verlag, 1996.

Müller A. Weltanschauung - eine Herausforderung für Martin Heideggers Philosophiebegriff. Stuttgart: Kohlhammer, 2009.

\section{References}

Diomyn, Y. V. (2015). Sootnoshenye nauky y myrovozzrenyia v svete fundamentalnoi ontolohyy M. Hajdeggera [Correlation of science and worldview in the light of M. Heideer's fundamental ontology M. Khaidegera]. Vestnyk SHAU [SSAU Bulletin], 1 (14), 225-234 [in Russian].

Heidegger, M. (2010). Davoser Disputation zwischen Ernst Cassirer und Martin Heidegger. Kant und das Problem der Metaphysik. Frankfurt am Main: Vittorio Klostermann Verlag.

Heidegger, M. (2005). Die Grundprobleme der Phänomenologie (Sommersemester 1927). Frankfurt am Main: Vittorio Klostermann Verlag.

Heidegger, M. (1999). Die Idee der Philosophie und das Weltanschauungsproblem (Kriegsnotsemester 1919). Frankfurt am Main: Vittorio Klostermann Verlag.

Heidegger, M. (2000). Die Überwindung der Metaphysik.Vorträge und Aufsätze (1936-1953). Frankfurt am Main: Vittorio Klostermann Verlag. 
Heidegger, M. (2003). Die Zeit des Weltbildes. Holzwege (1935-1946). Frankfurt am Main: Vittorio Klostermann Verlag.

Heidegger, M. (1996). Nietzsche: Der Wille zur Macht als Kunst (Winter semester 1936/37). Frankfurt am Main: Vittorio Klostermann Verlag.

Heidegger, M., \& Chernyakov A. G. (Trans). (2001). Osnovnye problemy fenomenologii [Basic problems of phenomenology]. Sankt-Peterburg: Vysshaya religiozno-filosofskaya shkola [in Russian].

Husserl, E. (2005). Fylosofyia kak strohaia nauka [Philosophy as a rigorous science]. In Yzbrannye raboty [Selected works] (pp. 185-240). Moskva: Yzdatelskyi dom „Terrytoryia budushcheho“" [in Russian].

Müller, A. (2009). Weltanschauung - eine Herausforderung für Martin Heideggers Philosophiebegriff. Stuttgart: Kohlhammer.

Mykhailov, Y. A. (1999). Rannyi Khaidehher: mezhdu fenomenolohyei y fylosofyei zhyzny [Early Heidegger: between phenomenology and philosophy of life]. Moskva: Prohress-Tradytsyia [in Russian].

Safransky, R. (2005). Hajdegger: germanskyi master i ego vremia [Heidegger: the German master and his time]. Moskva: „Molodaya gvardyia“ [in Russian].

Popov V. Y.

\section{DASEIN AND WELTANSHCAUUNG: HEIDERGGER'S EXPLANATIONS OF WORLDVIEW}

The study reveals the features of understanding and interpretation of the concept of "Weltanschauung" in the philosophy of Martin Heidegger. A certain evolution of his views is traced from "Ideas of Philosophy and Problems of Worldview" (1919) to "The Time of World Pictures" (1938). Heidegger's initial understanding of the concept of "worldview" was based on his commitment to the phenomenological philosophy of Husserl. Heidegger criticizes the relationship between philosophy and worldview, formed in neo-Kantianism and the "philosophy of life." In his first work devoted to the problem of the correlation of worldview and philosophy, he expresses the original assumption of an independent, parallel coexistence of these spheres of human spirituality. The further evolution of Heidegger's views was influenced by his fruitful collaboration with C. Jaspers. Under his influence, Heidegger finally separates himself with a neo-Kantian (school) understanding of the worldview.

He in The Fundamental Problems of Phenomenology (1927) produces an etymological and phenomenological destruction of the concept of Weltanschauung. Heidegger scrutinizes the origin of this concept from J. Cant's Critique of Judgment, to K. Jaspers' Psychology of Worldviews. Based on the analysis, Heidegger claims the final demarcation of philosophy and worldview and the origin of the latter from Dasein.

He claims that the worldview arises from the actual Dasein, with him and for him. " Philosophy (ontology) is the doctrine of being m mediated by existential analytics Dasein. The worldview thereby turns into one of the "existentials" of Dasein. The worldview is not the only or even priority topic of philosophy; it interests philosophy only to the extent that the problem of the essence of the world as a whole is an integral characteristic of human being-in-the-world. 
Heidegger carries out the final philosophical destruction of the concept of "Weltanschauung" in the work "Time of a picture of the world" (1938). He argues that the concept of "worldview" is historically determined. The worldview as such only in the modern era becomes the dominant way of self-understanding of man and understanding of the world. "As the world becomes a picture, a person's position is understood as a worldview," Heidegger proclaims. He strongly objects to the use of this concept in the spirituality of other eras and other cultures. The emergence of the concept of "worldview" is a testament to the emergence in the modern era of a new world interpretation and a new type of attitude towards the world and a new life position. Heidegger criticizes this technocratic worldview and calls for a return to the true origins of being.

The findings state that Heidegger's understanding of the concept of "worldview" is based on his recognition of its transient and historically determined nature. The Heidegger worldview is a product of the objectified science of the New Age and is a reflection of the human Dasein in the modern era. True Heidegger philosophy should limit the use of the artificial term "worldview," applying it only to a specific form of world interpretation of the Modern era.

Key words: Dasein, Weltanshcauung, worldview, phenomenology, existential analytics, Nazi ideology, Weltbild, picture of the world, deconstruction. 